\title{
Fibrosis Stage as a Predictor of Outcome after Resection for Hepatocellular Carcinoma
}

\author{
MAHMOUD H. ALLAM, M.D.*; MOHAMED A.S. KOHLA, M.D.*; ALIAA SABRY, M.D.*; \\ OSAMA HIGAZY, M.D.**; WALEED ABOGHARBIA, M.Sc.*** and ASHRAF ABOGABAL, M.D.* \\ The Departments of Hepatology \& Gastroenterology* and Hepatobiliary Surgery**, National Liver Institute, \\ Menoufiya University and Kobry Al-Qubaa Military Hospital, Cairo***, Egypt
}

\begin{abstract}
Background: As liver stiffness measured by FibroScan ${ }^{\circledR}$ can reflect the degree of liver fibrosis, liver stiffness measurement can predict the liver functional reserve.

Aim of Study: To evaluate the relationship between liver fibrosis stage and the risk of post-operative hepatic decompensation in patients with liver cirrhosis undergoing hepatectomy for hepatocellular carcinoma.

Patients and Methods: This prospective study was conducted on forty adult patients with HCV-related HCC eligible for hepatic resection between May 2015 and February 2017. Liver stiffness measurement by Fibroscan ${ }^{\circledR}$ was prospectively done for all enrolled patients. Patients' demographics, comorbidities, laboratory and radiological data were collected.

Results: Hepatic decompensation occurred in 14 patients (35\%) after liver resection. Analysis of ROC curve of liver stiffness measurement done before resection revealed a value equal to or higher than $15.4 \mathrm{KPa}$ as the best cutoff value for liver fibrosis stage predicting post-operative hepatic decompensation with a sensitivity of $100 \%$; specificity $100 \%$, a positive predictive value $100 \%$ and negative predictive value of $100 \%$.

Conclusion: Liver stiffness measurement by transient elastography (Fibroscan $\left.{ }^{\circledR}\right)$ may be a reliable tool to predict hepatic decompensation after liver resection for HCC.
\end{abstract}

Key Words: Liver Stiffness - Elastography - Fibroscan Fibrosis - Hepatocellular carcinoma resection Hepatitis $C$.

\section{Introduction}

HEPATOCELLULAR Carcinoma (HCC) is the most frequent primary neoplasm of the liver, the sixth most common malignancy ever and third cause of cancer related mortality worldwide [1]

Surgical resection of the tumor is considered a potentially curative treatment for patients with

Correspondence to: Dr. Mahmoud H. Allam, E-Mail: drmahmoudallam77@gmail.com
HCC. However, HCC is a complex tumor that often develops on a background of chronic liver disease especially liver cirrhosis [2].

Although, the prognosis of patients referred to liver resection has improved substantially in the recent years attributed to advances in perioperative patient evaluation, surgical technique, and intensive care management, life threatening complications can still develop in some patients who undergo liver resection for Hepatocellular Carcinoma (HCC), the most dreadful of which is Post-operative Liver Failure (PLF) [2].

Assessment of post-operative outcome is a crucial step in HCC management before surgical resection and any attempt to assess for the outcome should consider not only tumor related factors but also the functional hepatic reserve which determine the feasibility and the expected complication after all known therapeutic options including resection [3]

Several scores and stratification systems such as Barcelona Clinic Liver Cancer (BCLC) staging system and Model for End stage Liver Disease (MELD) score, have been proposed for proper preoperative appraisal of hepatic functional reserve which aimed to decrease the risk of post-operative morbidity and mortality [4].

Indocyanine Green (ICG) clearance test is used for quantitative liver function reserve assessment in Asian countries and is increasingly used in other parts of the world. However it is an expensive and time consuming test [5].

Liver fibrosis or cirrhosis result in increased Liver Stiffness (LS). Transient Elastography measured by FibroScan ${ }^{\circledR}$, an ultrasound-based modality, 
is considered an easy, rapid and reproducible method that can be used to quantitatively assess LS as a surrogate for liver fibrosis [6]. But, with certain limitations in obese patients and those with ascites and unreliable results in patients with acute hepatitis and elevated serum transaminases level [7]. As liver stiffness measured by FibroScan ${ }^{\circledR}$ can reflect the degree of liver fibrosis, liver stiffness measurement can predict the liver functional reserve $[\mathbf{8 , 9 ]}$

The aim of this work was to assess the predictive value of LS measurement by transient elsatography (FibroScan ${ }^{\circledR}$ ) on the risk of post-operative hepatic decompensation, and consequently the prognosis of patients undergoing hepatectomy for HCC.

\section{Patients and Methods}

\section{Study group:}

After approval of the local Institutional Review Board (IRB), 40 adult patients with HCV-related HCC presented at National Liver Institute (NLI), Menoufiya University between May 2015 and February 2017 were enrolled in this study. All patients met the inclusion criteria of the study and signed an informed consent to participate in this study.

\section{Inclusion criteria:}

Patients with HCV-related HCC eligible for hepatic resection.

\section{Exclusion criteria:}

Patients with decompensated cirrhosis (child C), those with un-resectable tumors and those with recurrent tumors patients with portal vein thrombosis were excluded from this study.

Pre-operative assessment, including patient demographics, comorbidities, laboratory investigations (CBC, liver function tests, renal function tests, serology for HBV and $\mathrm{HCV}$ viral infections and serum AFP) and radiological findings (abdominal ultrasound and triphasic computed tomography) were performed to all patients. Child-Pugh and the Model for End stage Liver Disease (MELD) scores were calculated.

\section{Liver stiffness measurement:}

Liver stiffness measurement using Fibroscan ${ }^{\circledR}$ was performed for all patients within one week before surgery using fibroscan $504 \AA$ machine, echosens, France. Only results with ten valid measurements and a success rate of at least $60 \%$ and the interquartile range lower than $30 \%$ of the median value were considered reliable. The results were expressed in kilopascals $(\mathrm{kPa})[\mathbf{1 0 , 1 1 ]}$
Surgical procedure: Selected patients underwent hepatic resection of liver HCC focal lesions according to the standard protocols of Surgery and Anesthesia Departments. Left hepatectomy, right hepatectomy or segmentectomy were selected on case-by-case basis.

According to BCLC, only patients with BCLC stages 0 and $\mathrm{A}$ (Child class A cirrhosis) were eligible for surgical resection of HCC, however, this was exceeded in this study which included some patients with early Child class B cirrhosis and small tumors.

Post-operative follow-up: For evaluating postoperative complications, development of ascites was considered the most relevant sign of hepatic decompensation [12]. Post-operative Liver Failure (PLF) was defined as both a prothrombin concentration less than $50 \%$ (International Normalised Ratio (INR) >1.7) and a serum bilirubin concentration greater than $50 \mathrm{mmol} / \mathrm{L}$ on fifth postoperative day $[13,14]$

Statistical analysis: Patient characteristics were expressed as the mean $\pm \mathrm{SD}$ or median (range). Continuous variables were compared using an independent $t$-test and categorical variables were analyzed using chi-square test or Fisher's exact test. A two-sided $p$-value $<0.05$ was considered significant.

Variables associated with the development of postoperative hepatic insufficiency which were significant at a $p<0.10$ in the univariate analyses were subjected to multivariate logistic regression analyses to identify independent predictors for the development of post-operative hepatic insufficiency. The diagnostic accuracy of the identified risk factors was evaluated using Receiver Operating Curve (ROC). A $p$-value of less than 0.05 was considered statistically significant. SPSS 21.0 for Windows was used for all statistical analyses [15]

\section{Results}

Patients and tumor characteristics: The baseline characteristics of patients are summarized in (Table $1)$. Forty patients were included in this study, nine females $(22.5 \%)$ and thirty one males $(77.5 \%)$ with a mean age of 52.5 years. Twenty nine patients were Child-Pugh score class A (72.5\%) and 11 patients $(27.5 \%)$ were Child-Pugh class B. The mean pre-operative MELD score calculated for the patients was $(8.5 \pm 1.84)$.

All patients were subjected to upper GI endoscopy before liver resection, nineteen of them had small esophageal varices $(47.5 \%)$ and twenty one had no esophageal varices $(52.5 \%)$, while none 
had gastric varices. Pre-operative abdominal ultrasonography revealed that none of these patients had ascites.

Liver stiffness measurement by transient elastography (fibroscan $®$ ) was done to all patients with no dropouts. The mean level of liver elasticity measured was $16.19 \pm 5.62 \mathrm{kPa}$.

The size of liver HCC focal lesions were variable on pre-operative Computed Tomography (CT). Twenty one patients $(52.5 \%)$ had small focal lesions $(<3 \mathrm{~cm})$ while nineteen patients $(47.5 \%)$ patients had a larger focal lesions. As regards the number of focal lesions, 27 patients $(67.5 \%)$ had single focal lesion, 12 patients $(30 \%)$ had two focal lesions and one patient $(2.5 \%)$ had 3 focal lesions.

On analysis of patients' pre-operative data, the patients' gender, the mean age, the number of focal lesions and presence of esophageal varices were not independent risk factors in predicting liver insufficiency after liver resection. In addition, the pre-operative MELD score, Hemoglobin level, WBCs, ALT, AST, Serum Creatinine and INR had no significance in predicting post-operative decompensation.

While the pre-operative serum Albumin, Platelets count and serum Bilirubin had a low significance in predicting post-operative decompensation, the tumor size, CTP score and pre-operative liver Transient Elastography measurement were highly correlated with post-operative liver insufficiency development.
Post-operative course and identification of risk factors in predicting post-operative hepatic insufficiency:

All patients were followed-up daily during hospital stay and re-evaluation for development of post-operative hepatic insufficiency was done weekly for one month after resection. Twenty six patients didn't develop any sign of liver decompensation after resection (group I), while evident Hepatic insufficiency developed in 14 patients (35\% of the studied patients ), (group II), (Table 2).

Table (1): Pre-operative demographic data of enrolled patients.

\begin{tabular}{ll}
\hline Variables & \multicolumn{1}{c}{$\begin{array}{c}\mathrm{N}(\%) \text {, mean } \pm \mathrm{SD}, \\
\text { or median (range) }\end{array}$} \\
\hline Male/female & $31(77.5 \%) / 9(22.5 \%)$ \\
Age (years) & $52.5 \pm 7.445$ \\
Hemoglobin $(\mathrm{g} / \mathrm{dl})$ & $11.703 \pm 1.304$ \\
White blood cell count $\left(10{ }^{3} / \mathrm{l}\right)$ & $6340.0 \pm 2243.0$ \\
Platelet count $(10 / \mathrm{l})$ & $104.825 \pm 37.392$ \\
Albumin $(\mathrm{mg} / \mathrm{dl})$ & $3.280 \pm 0.386$ \\
Total bilirubin $(\mathrm{mg} / \mathrm{dl})$ & $0.973 \pm 0.157$ \\
ALT $(\mathrm{IU} / \mathrm{l})$ & $49.300 \pm 18.361$ \\
AST $(\mathrm{IU} / \mathrm{l})$ & $56.575 \pm 20.529$ \\
Serum creatinine $(\mathrm{mg} / \mathrm{l})$ & $0.913 \pm 0.234$ \\
Prothrombin time $(\mathrm{seconds})$ & $12.950 \pm 0.639$ \\
Esophageal varices & $19(47.5 \%)$ \\
CTP class A/CTP class B & $29(72.5) / 11(27.5)$ \\
MELD score & $8.5 \pm 1.84$ \\
Transient Elastography $(\mathrm{kPa})$ & $16.19 \pm 5.62$ \\
Size of focal lesions $(<3 \mathrm{~cm} />3 \mathrm{~cm})$ & $21(52.5) / 19(47.5)$ \\
Number of focal lesions: & \\
$\quad$ Single & $27(67.5 \%)$ \\
Two focal lesions & $12(30 \%)$ \\
Three focal lesions & $1 \quad(2.5 \%)$ \\
\hline
\end{tabular}

Table (2): Post-operative data of enrolled patients.

\begin{tabular}{lllc}
\hline Variables & Group I $(\mathrm{n}=26)$ & Group II $(\mathrm{n}=14)$ & $p$-value \\
\hline Male/female & $21(80.77 \%) / 5(19.23 \%)$ & $10(71.43 \%) / 4(28.57 \%)$ & 0.505 \\
Age $($ years) & $52.577 \pm 7.700$ & $52.429 \pm 7.229$ & 0.285 \\
Hemoglobin $(\mathrm{g} / \mathrm{dl})$ & $11.850 \pm 0.883$ & $11.429 \pm 1.864$ & 0.336 \\
White blood cell count $\left(10^{3} / \mathrm{l}\right)$ & $6365.0 \pm 2112.428$ & $6292.857 \pm 2553.268$ & 0.924 \\
Platelet count $(10 / \mathrm{l})$ & $112.005 \pm 42.377$ & $90.571 \pm 20.110$ & 0.077 \\
Albumin $(\mathrm{mg} / \mathrm{dl})$ & $3.369 \pm 0.390$ & $3.114 \pm 0.332$ & 0.045 \\
Total bilirubin $(\mathrm{mg} / \mathrm{dl})$ & $0.938 \pm 0.142$ & $1.036 \pm 0.169$ & 0.06 \\
ALT $(\mathrm{IU} / \mathrm{l})$ & $51.962 \pm 15.074$ & $44.357 \pm 23.107$ & 0.216 \\
AST $(\mathrm{IU} / \mathrm{l})$ & $60.192 \pm 20.008$ & $49.857 \pm 20.486$ & 0.131 \\
Serum creatinine $(\mathrm{mg} / \mathrm{l})$ & $0.923 \pm 0.203$ & $0.893 \pm 0.292$ & 0.703 \\
Prothrombin time/sec & $12.923 \pm 0.628$ & $13.000 \pm 0.679$ & 0.721 \\
Esophageal varices & $10(38.46 \%)$ & $9(64.29 \%)$ & 0.117 \\
MELD score & $8.269 \pm 1.663$ & $8.929 \pm 2.129$ & 0.285 \\
Pre-operative CTP score: & & & $<0.001$ \\
$\quad$ CTP A & $25(96.15 \%)$ & $4(28.57 \%)$ & \\
CTP B & $1(3.85 \%)$ & $10(71.43 \%)$ & $<0.001$ \\
Size offocal lesions: & & & \\
$\quad$ Small & $19(73.08 \%)$ & $12(85.71 \%)$ & $<0.001$ \\
$\quad$ Large & $7(26.92 \%)$ & $20.321 \pm 8.033$ & \\
Transient Elastography/kPa & $13.977 \pm 1.049$ & &
\end{tabular}


The mean FibroScan value for patients who developed post-operative hepatic insufficiency was $22.321 \pm 8.033 \mathrm{Kpa}$ which was significantly higher than that of patients who did not $(13.977 \pm 1.049$ $\mathrm{Kpa}, p<0.001$ ).

ROC curve analysis of pre-operative LSM identified a LS value equal to or higher than $15.4 \mathrm{KPa}$ has the best cutoff value for predicting postoperative hepatic insufficiency. This cutoff value gave the best statistical accuracy (sensitivity $100 \%$; specificity $100 \%$ Fig. (1), with a positive predictive value $100 \%$; and negative predictive value of $100 \%)$.

Patients with high LS (more than $15.4 \mathrm{kPa}$ ) had lower post-operative serum albumin levels $(<3$ $\mathrm{gm} / \mathrm{dl}$ ); higher serum bilirubin ( $\geq 2 \mathrm{mg} / \mathrm{dl}$ ), lower platelet count, and higher probability of developing post-operative ascites.

Patients with CTP class B were more liable to develop post-operative decompensation, with sensitivity (71.43), specificity (96.9\%) and (91\%) positive predictive value and $(90.91 \%)$ negative predictive value with accuracy $87.50 \%$.

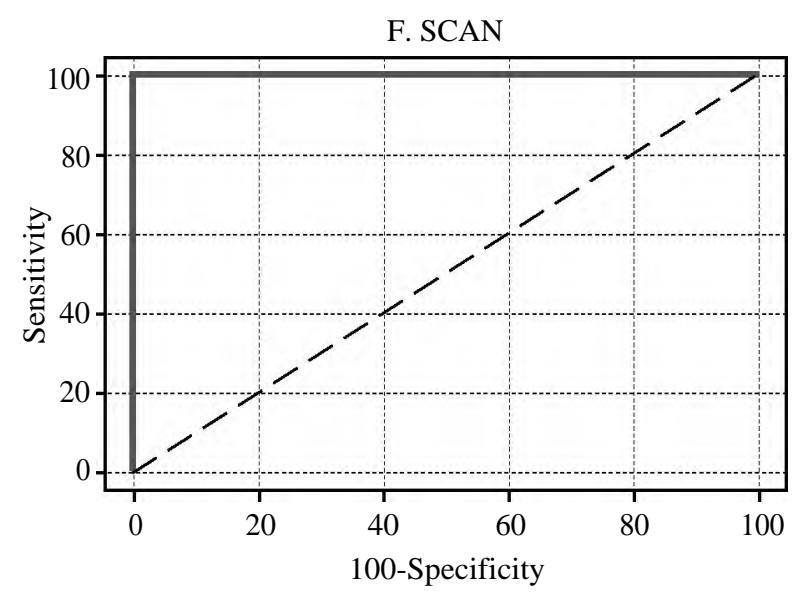

Fig. (1): ROC curve of pre-operative LSM as a predictor of post-operative hepatic insufficiency.

\section{Discussion}

Development of HCC is a major health problem and selecting the best treatment option for each patient at different tumor stage depends not only on the tumor stage but also on the functional hepatic reserve and performance of the patient (which are taken into consideration in BCLC staging system).

Potentially curative treatment modalities for HCC include liver transplantation, liver resection, and loco-regional ablative therapy. Transplantation offers treatment of both $\mathrm{HCC}$ and the underlying liver cirrhosis. However, with the limitation and shortage of available donors, only a minority of patients are finally referred to transplantation. Therefor surgical hepatic resection for curative purpose can be widely applied to a larger set of patient with HCC. However it carries the risk of post-operative hepatic decompensation due to inadequate functional reserve of the remnant liver [16].

Careful pre-operative assessment of the functional hepatic reserve remains a major challenge to minimize the peri-and post-operative morbidity and mortality $[\mathbf{1 7 , 1 8}]$. Several methods are available for this purpose including serum Hyaluronic acid assay, volumetric assessment of the remnant liver and ICG clearance test, which is the most commonly used method for quantitative liver function reserve assessment in Asian countries. However, they are expensive and time consuming [5] .

Previous reports suggested the use of noninvasive methods for assessing the liver stiffness by transient elastography (Fibroscan ${ }^{\circledR}$ ) as a rapid, easily performed and accessible method for the diagnosis of liver fibrosis, cirrhosis and portal hypertension [19-23].

A cut-off value of $14 \mathrm{Kpa}$ was suggested by Sanchez-Conde and his colleagues, for prediction of portal hypertension in $\mathrm{HIV} / \mathrm{HCV}$-co-infected patients [19]. Moreover, Chuan et al., reported a cut-off value of $15.6 \mathrm{Kpa}$ to predict post-operative ascites after liver resection for hepatitis B virusrelated HCC [22].

In our study, liver stiffness measured by FibroScan ${ }^{\circledR}$ was the best predictor of hepatic insufficiency in patients undergoing liver resection for $\mathrm{HCC}$, with an impact significantly higher than any other studied variable and subsequent ROC curve analysis of pre-operative Liver Stiffness Measurement (LSM) identified an LS value equal to or higher than $15.4 \mathrm{KPa}$ as the best cut-off value for predicting post-operative hepatic insufficiency in this patients cohort. Similarly, Cescon et al., also indicated that pre-operative liver stiffness measurement by Fibroscan, contributed to postoperative liver failure with a the cut-off value of 15.7Kpa [23] and, Kim SU et al., concluded that, that pre-operative LSM was the only independent risk factor for predicting the development of postoperative hepatic insufficiency (cut-off, $25.6 \mathrm{kPa}$; $p=0.001$; relative risk, $19.14 ; 95 \%$ confidence interval, 2.71-135.36) [8].

In a study by Kim SH et al., 2013 who tried to identify predictors of mortality from irreversible PHLF, he assumed that patients with chronic liver 
disease who will undergo liver resection the combination of $\mathrm{PT}<65 \%$ and bilirubin $>38 \mathrm{~g} \mathrm{~mol} / \mathrm{L}$ may be a more sensitive predictor of mortality from PHLF [24]

Our study showed that pre-operative serum bilirubin had low statistical significance. However, INR didn't have any significance in predicting post-operative liver failure.

In our study, pre-operative Child-Pugh classification was highly significant in predicting postoperative liver failure with sensitivity (71.43), specificity $(96.9 \%)$ and $(91 \%)$ positive predictive value and $(90.91 \%)$ negative predictive values.

Nonetheless, the presence of esophageal varices had no statistical significance as a predictor of post-operative decompensation. No correlation was doe between the presence of varices with elastography.

A study by Chen X et al., 2012, demonstrated that patients with Child-Pugh class A cirrhosis and clinical evidence of portal hypertension are likely to develop Post-Hepatectomy Liver Failure (PHLF). This study explored the impact of Portal Venous Pressure (PVP) on PHLF and the possibility of stratifying patients with Child-Pugh grade A cirrhosis for risk of PHLF using clinical data alone [25].

\section{Conclusion:}

In conclusion, our results suggest that LS measured by FibroScan is a potentially reliable tool to predict post-operative hepatic decompensation in patients undergoing surgical resection for hepatocellular carcinoma and at a certain cut-off value can identify patients who have a higher probability of post-operative morbidity and mortality and should be considered as an important part of preoperative evaluation of those patients.

\section{References}

1- FERLAY J., SOERJOMATARAM I., DIKSHIT R., ESER S., MATHERS C., REBELO M., PARKIN D.M., FORMAN D. and BRAY F.: Cancer incidence and mortality worldwide: Sources, methods and major patterns in GLOBOCAN 2012. Int. J. Cancer, 136: E359-E86, 2015.

2- JARNAGIN W.R., GONEN M., FONG Y., DeMATTEO R.P., BEN-PORAT L., LITTLE S., CORVERA C., WEBER S. and BLUMGART L.H.: Improvement in perioperative outcome after hepatic resection: Analysis of 1,803 consecutive cases over the past decade. Ann. Surg., 236: 397-406, 2002.

3- FORNER A., DÍAZ-GONZÁLEZ A., LICCIONI A. and VILANA R.: Prognosis, prediction and staging. Best Pract. Res. Clin. Gastroenterol., 28: 855-65, 2014.
4- BRUIX J., REIG M. and SHERMAN M.: Evidence-based diagnosis, staging, and treatment of patients with hepatocellular carcinoma. Gastroenterology, 150: 835-53, 2016.

5- LAU H., MAN K., FAN S.T., YU W.C., LO C.M. and WONG J.: Evaluation of pre-operative hepatic function in patients with hepatocellular carcinoma undergoing hepatectomy. Br. J. Surg., 84: 1255-9, 1997.

6- SANDRIN L., FOURQUET B., HASQUENOPH J.M., YON S., FOURNIER C., MAL F., CHRISTIDIS C., ZIOL M., POULET B., KAZEMI F., BEAUGRAND M. and PALAU R.: Transient elastography: A new noninvasive method for assessment of hepatic fibrosis. Ultrasound Med. Biol., 29: 1705-13, 2003.

7- CASTERA L., FOUCHER J., BERNARD P.H., CARVALHO F., ALLAIX D., MERROUCHE W., COUZIGOU P. and De LÉDINGHEN V.: Pitfalls of liver stiffness measurement: A 5-year prospective study of 13,369 examinations. Hepatology, 51: 828-35, 2010.

8- S.U. KIM, S.H. AHN, J.Y. PARK, Y. KIM DO, C.Y. CHON, J.S. CHOI, K.S. KIM and K.H. HAN: Prediction of post-operative hepatic insufficiency by liver stiffness measurement (FibroScan $((\mathrm{R}))$ before curative resection of hepatocellular carcinoma: A pilot study, Hepatol. Int., 2 (4): 471-7, 2008.

9- M. ZIOL, A. HANDRA-LUCA, A. KETTANEH, C. CHRISTIDIS, F. MAL, F. KAZEMI, V. De LEDINGHEN, P. MARCELLIN, D. DHUMEAUX, J.C. TRINCHET and M. BEAUGRAND: Noninvasive assessment of liver fibrosis by measurement of stiffness in patients with chronic hepatitis C, Hepatology, 41 (1): 48-54, 2005.

10- K.S. JUNG, S.U. KIM, S.H. AHN, Y.N. PARK, Y. KIM DO, J.Y. PARK, C.Y. CHON, E.H. CHOI and K.H. HAN: Risk assessment of hepatitis B virus-related hepatocellular carcinoma development using liver stiffness measurement (FibroScan). Hepatology, 53 (3): 885-94, 2011.

11- K.S. JUNG, S.U. KIM, G.H. CHOI, J.Y. PARK, Y.N. PARK, Y. KIM DO, S.H. AHN, C.Y. CHON, K.S. KIM, E.H. CHOI, J.S. CHOI and K.H. HAN: Prediction of recurrence after curative resection of hepatocellular carcinoma using liver stiffness measurement (FibroScan (R)), Ann. Surg. Oncol., 19 (13): 4278-86, 2012.

12- J. FIGUERAS, L. LLADO, D. RUIZ, E. RAMOS, J. BUSQUETS, A. RAFECAS, J. TORRAS and J. FABREGAT: Complete versus selective portal triad clamping for minor liver resections: A prospective randomized trial, Ann. Surg., 241 (4): 582-90, 2005.

13- S. BALZAN, J. BELGHITI, O. FARGES, S. OGATA, A. SAUVANET, D. DELEFOSSE and F. DURAND: The "50e50 criteria" on post-operative day 5: An accurate predictor of liver failure and death after hepatectomy. Ann. Surg., 242 (6): 824-8, 2005.

14- C. PAUGAM-BURTZ, S. JANNY, D. DELEFOSSE, S. DAHMANI, F. DONDERO, J. MANTZ and J. BELGHITI: Prospective validation of the "fifty-fifty" criteria as an early and Accurate predictor of death after liver resection in intensive care unit patients, Ann. Surg., 249 (1): 1248, 2009.

15- C. LI, K. MI, T. WEN, L. YAN, B. LI, J. YANG, M. XU, W.T. WANG and Y. WEI: A learning curve for living donor liver transplantation, Dig. Liver Dis., 44 (7): 597602, 2012. 
16- SONG T.J., IP E.W. and FONG Y.: Hepatocellular carcinoma: Current surgical management. Gastroenterology, 127 (1): S248-S260, 2004.

17- LAU H., FAN S.T., NG I.O. and WONG J.: Long term prognosis after hepatectomy for hepatocellular carcinoma: A survival analysis of 204 consecutive patients. Cancer, 83: 2302-11, 1998.

18-NOGUCHI T., IMAI T. and MIZUMOTO R.: Pre-operative estimation of surgical risk of hepatectomy in cirrhotic patients. Hepatogastroenterology, 37: 165-71, 1990.

19- M. SANCHEZ-CONDE, P. MIRALLES, J.M. BELLON, D. RINCON, M. RAMIREZ, I. GUTIERREZ, C. RIPOLL, J.C. LOPEZ, J. COSIN, G. CLEMENTE, O. LO IACONO, R. BANARES and J. BERENGUER: Use of transient elastography (FibroScan $(\mathrm{R}))$ for the noninvasive assessment of portal hypertension in HIV/HCV-coinfected patients, J. Viral Hepat., 18 (10): 685-91, 2011.

20- L. CASTERA, M. PINZANI and J. BOSCH: Noninvasive evaluation of portal hypertension using transient elastography, J. Hepatol., 56 (3): 696-703, 2012.

21- C. BUREAU, S. METIVIER, J.M. PERON, J. SELVES, M.A. ROBIC, P.A. GOURRAUD, O. ROUQUET, E. DUPUIS, L. ALRIC and J.P. VINEL: Transient elastog- raphy accurately predicts presence of significant portal hypertension in patients with chronic liver disease, Aliment. Pharmacol. Ther., 27 (12): 1261-8, 2008.

22- CHUAN LI A., JING-YI ZHANG B., XIAO-YUN ZHANG A., TIAN-FU WEN A. and LU-NAN YAN A.: FibroScan predicts ascites after liver resection for hepatitis B virus related hepatocellular carcinoma: A prospective cohort study. International Journal of Surgery, 20: 21-5, 2015.

23- CESCON M.1, COLECCHIA A., CUCCHETTI A., PERI E., MONTRONE L., ERCOLANI G., FESTI D. and PINNA A.D.: Value of transient elastography measured with FibroScan in predicting the outcome of hepatic resection for hepatocellular carcinoma. Ann. Surg., 256 (5): 706-12, 2012.

24- KIM S.H., KANG D.R., LEE J.G., KIM D.Y., AHN S.H., HAN K.H., CHON C.Y. and KIM K.S.: Early predictor of mortality due to due to irreversible posthepatectomy liver failure in patients with hepatocellular carcinoma. World J. Surgery, 37 (5): 1028-33, 2013.

25- CHEN X., ZHAI J., CAI X., ZHANG Y., WEI L., SHI L., WU D., SHEN F., LAU W.Y. and WU M.: Severity of portal hypertension and prediction of post-operative liver failure after liver resection in patients with Child Pugh grade A cirrhosis. Br. J. Surg., 99 (12): 1701-10, 2012.

\title{
التليف مرحلة تنبئ بالنتيجة بعل إستئصال السرطان الكبد
}

\author{
نظراً لآن تصلب الكبد الذى يتم قياسه بواسطة BFibroScan يمكن آن يعكس درجة تليف الكبد، فإن قياس تصلب الكبد يمكن آن يتباً \\ بإحتياطى وظائف الكبد. \\ حيث تهدف هذه الدراسة إلى تقييم العلاقة بين مرحلة تليف الكبد وخطر إزالة الودم بالكبد بعد العملية الجراحية في المرضى الذين يعانون

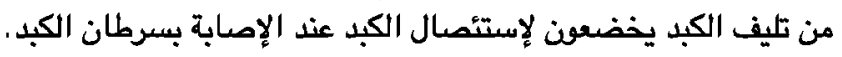 \\ وقد آجريت هذه الدراسة الإستطلاعية على آربعين من المرضى البالغين الذين يعانف من سرطان الكبد الوبائى المرتبط بفيروس إلتهاب

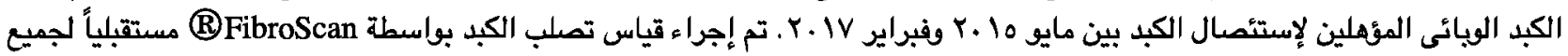 \\ المرضى المسجلين. تم جمع التركيبة السكانية للمرضى والإعتلالات المصاحبة والبيانات المختبرية والإثعاعية.

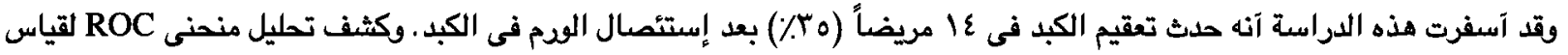

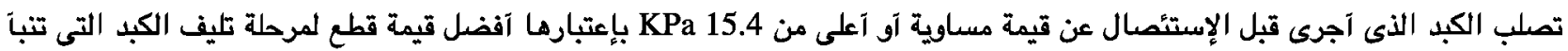

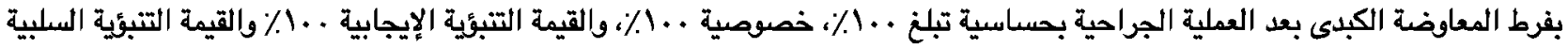

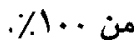 \\ ونستخلص من هذه الدراسة آنه قد يكن قياس تصلب الكبد عن طريق الإلاسترافيا المؤقتة RFibroScan آداة موثققة للتنبؤ بفقدان

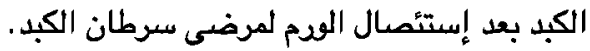

